\title{
Arkitektoniske momenter
}

Etiske og æstetiske refleksioner hos den tidlige Bachtin

\begin{abstract}
»Jeg og den anden er de grundlæggende værdikategorier, som for første gang muliggør enhver konkret værditillæggelse, og værditillæggelsesmomentet, eller snarere momentet af bevidsthedens værditillæggende holdning, er ikke kun til stede i en faktisk handling, men også i enhver levet erfaring og selv i den mest enkle sansning: At leve betyder at indtage en aksiologisk position i hvert øjeblik af ens liv eller at placere sig selv i forhold til værdier.« M.M. Bachtin ${ }^{1}$
\end{abstract}

Mødet med Michail M. Bachtins forfatterskab kan minde om synet af en kubistisk collage. Hans bøger, essays og tekstfragmenter afsætter betydninger og perspektiver, der peger i lige så forskellige retninger som collagens overvældende ophobning af stofrester og avisudklip, fotografier og cigaretpakker. Og ligesom collagen - i det vellykkede kunstværk - kan samle sig til en nærmest klassisk, omend åben form for helhed, besidder Bachtins forfatterskab en egen omdrejningsakse, som giver det en indre dynamik og sammenhæng - uden at dette betyder, at de forskellige og til tider uforenelige perspektiver restløst kan ophæves i en syntetisk enhed.

Denne dobbelthed af mangfoldige perspektiver og indre dynamik er blevet yderligere bekræftet efterhånden som den tidlige del af Bachtins forfatterskab har set dagens lys. Der er tale om tekster, som først blev udgivet lang tid efter, Bachtin fik sit egentlige gennembrud i Vesten med sine bøger om Dostojevskij og Rabelais, og det er muligt, at udgivelsen af disse tidlige skrifter kan sætte lidt mere form på den til tider uhyre forvirrede Bachtin-forståelse, der som Paul de Man maliciøst har bemærket kan gøre Bachtin til alt fra analytisk filosof over heideggeriansk ontolog til religiøs fænomenolog eller receptionsæstetiker. ${ }^{2}$ Det er i hvert fald vores opfattelse, at man i disse tidlige tekster finder nogle indicier for, hvilke betoninger det er rimeligt at lægge ned over Bachtins senere forfatterskab. 
Og lad os med det samme slå fast, at den linje - eller intonation - i Bachtins hele værk, der står endnu stærkere frem med disse skrifter, er de udpræget moralske og eksistentielle problematikker, som især forbindes med æstetiske refleksioner, og i sidste instans gælder en forståelse af menneskets væren i verden, en filosofisk antropologi. ${ }^{3}$ Hermed skal det også være sagt, at den tidlige periode er 'de store spørgsmåls tid': Bachtin argumenterer for en moralfilosofisk funderet 'første filosofi' og en systematisk, filosofisk æstetik, og som sådan sætter han subjektets status, forholdet mellem jeg og den anden, etikkens mulighed og æstetikkens betydning i den menneskelige tilværelse til debat - og det er vel at mærke en tilværelse, som er hærget af moderniseringsprocessernes imperativer om fornuft, fornyelse og fremskridt $i$ den samtidige erodering af overleverede livsmønstre, normer og traditioner. Således behandler Bachtin emner og leverer sine fors $\emptyset$ gsvise svar som besidder en stadig aktualitet, og mens disse problematikker altså diskuteres eksplicit i hans tidlige tekster, så opleves de i det senere værk snarere som en fornemmelse, en strøm lige under teksternes overflade. Men spørgsmålet er, om det imidlertid ikke netop er denne understrøm, der har udgjort tiltrækningen for de mange Bachtin-interesserede - også før det blev muligt at dykke ned i og undersøge strømmens udspring?

Dette er baggrunden for, at vi har valgt at præsentere 'den tidlige Bachtin', dvs. hans skrifter fra 1919-1924: ${ }^{4} \gg$ Kunst og ansvarlighed « (1919), de to ufuldstændige manuskriptfragmenter »Mod en handlingens filosofi« (19191921), »Forfatter og helt i æstetisk aktivitet « (1920-1924) samt essayet »Problemet om indhold, materiale og form i verbal kunst « (1924). ${ }^{5} \mathrm{Vi}$ skal behandle skrifterne i den anførte rækkefølge, og efter gennemgangen af »Kunst og ansvarlighed « vil vi behandle de to store manuskriptfragmenter ud fra den grundtese, at de udgør fragmenter af et stort anlagt værk om etik, æstetik, politik og religion, som Bachtin arbejdede på i begyndelsen af 1920'erne, og som Holquist og Clark med en heldig formulering kalder Ansvarlighedens arkitektonik. ${ }^{6}$ Denne grundtese skaber en god sammenhæng og en forøget forståelse af Bachtins storstilede omend mislykkede projekt. Essayet »Problemet om indhold... « kan i denne forbindelse ses både som en videreførelse af de konklusioner, Bachtin kom til i Ansvarlighedens arkitektonik, og som en art overgangstekst til de senere perioder i Bachtins forfatterskab, bl.a. i kraft af en begyndende refleksion over sprogets betydning.

Dette kan også indikere, at vi ser Bachtins tidlige forfatterskab som en del af forfatterskabets store collage - den tidlige del besidder en egen selvstændighed på grund af en bestemt forståelse af æstetikken og den underbetonede, næsten fraværende sprogrefleksion, som adskiller den fra resten af forfatterskabet, men gennem dens temaer, dens eksistentielle problematikker og mo- 
ralsk-aksiologiske resonansbund forbliver den aktuel for en dybere forståelse af Bachtins forfatterskab som helhed.

\section{Kunst som ansvar}

Den første tekst man har kendskab til fra Bachtins hånd er en lille artikel på knap to sider, »Kunst og ansvarlighed «, der blev offentliggjort i en russisk provinsavis i 1919. Men trods dens lidenhed er artiklen særdeles bemærkelsesværdig, fordi den med næsten overmodige håndbevægelser udkaster en række af de temaer, der skulle blive konstituerende for Bachtins forfatterskab som helhed. Og samtidig bærer den i uudfoldet form præg af de to uforenelige filosofiske strømninger som den vesteuropæisk orienterede og uhyre belæste Bachtin var tydeligt påvirket af. Nemlig den rationalistiske, idealistisk inspirerede vidensskabsteoretiske tradition fra Kant over nykantianerne til fænomenologerne, Husserl og især Scheler, og den æsteticerende, fornufts- og videnskabskritiske livsfilosofi, repræsenteret af bl.a. Kierkegaard, dele af romantikken, Nietzsche, Bergson, Buber og i en vis udstrækning Simmel.

Bachtin søger i den tidlige del af forfatterskabet at sammentænke disse filosofiske strømninger, og i »Kunst og ansvarlighed « kan man høre et svagt ekko af Kants diskussion af de autonomiserede vidensområder: etik, videnskab og æstetik, en triade som præger hele perioden, selv om Bachtin i artiklen ikke behandler etikken som et selvgyldigt område og nærmest blot strejfer videnskaben - til fordel for en privilegering af kunsten. Denne livsfilosofiske accent bekræftes yderligere af, at Bachtin sætter de autonomiserede områder op mod livet. Det gælder en tematisering af det, han $\mathrm{i} » \operatorname{Mod}$ en handlingens filosofi« mere systematisk skal udlægge som adskillelsen mellem kultur- og livsverdenen, og efter Bachtins opfattelse er problemet netop, at kultur- og livsverdenen er faldet fra hinanden. På denne baggrund diagnosticerer han sin samtid som en mekanisk, falsk helhed, hvis enkelte dele kun er forenet i tid og rum, og hvor meningstab, menneskelig splittelse og mellemmenneskelig fremmedgørelse sætter dagsordenen. Dette er en diagnose af moderniseringsprocessernes effekt på den menneskelige tilværelse, og forestillingen om samtiden som kriseramt bringer tankerne hen på centrale europæiske positioner i mellemkrigstiden: den sene ekspressionisme, Freud, Adorno, Lukács mfl., ligesom den synes at trække veksler på den spæde, moderne sociologi.

Bachtins bud på en overvindelse af samtidens krise er imidlertid eksistensfilosofisk og romantisk farvet, især Kierkegaard og måske Schiller synes at rumstere i baggrunden, fordi over for den mekaniske helhed sætter Bachtin ideen om en integreret helhed, hvis elementer er gennemtrængt af en indre 
meningsenhed, og denne virkelige enhed er ansvaret, som kun det enkelte individ kan påtage sig. »Individet«, skriver han, »skal være fuldstændig ansvarligt: alle dets momenter skal ikke bare passe ind i en tidsmæssig rækkefølge i dets liv, men de skal også gennemtrænge hinanden i en enhed af skyld og ansvarlighed «(»AA«, p. 2). Og selv om det er lettere ikke at påtage sig ansvaret og skylden, så er denne holdning illegitim, pointerer Bachtin, og han nærmer sig hermed de eksistensfilosofiske grundfigurer omkring menneskets individuelle valg, der fører til, at mennesket enten kan realisere sig selv ved at påtage sig ansvaret og skylden, eller undvige ansvaret og skylden og dermed ende i en 'uegentlig' og splittet eksistens.

Trods pointens generaliserbarhed er det imidlertid centralt, at Bachtin primært reflekterer den æstetisk. Det er poeten, som skal huske, at hans poesi bærer skylden for livets vulgære prosa, ligesom det er hverdagens menneske, som bærer skylden for poesiens frugtesløshed (jvf. »AA«, p.2). Og snarere end en typisk avantgardistisk vision om sammensmeltningen af liv og kunst udgør dette Bachtins første fors $\emptyset \mathrm{g}$ på at tænke kunsten som en normativ størrelse - et væsentligt tema gennem hele forfatterskabet. ${ }^{7}$

På denne måde bærer »Kunst og ansvarlighed « i kimform på en række af de filosofiske, eksistentielle, moralske og æstetiske overvejelser omkring den egentlige og uegentlige eksistens, ansvarsforflygtigelse og ansvarstagen, kunstens normativitet og dens betydning i den menneskelige tilværelse, som Bachtin skal blive ved med at vende tilbage til, selvom begreberne forandres undervejs. Her skal vi imidlertid kun følge temaerne gennem de tidlige skrifter for at se, hvorledes de tager form i en udfoldet udgave.

\section{Ansvarlighedens arkitektonik}

Bachtin kastede sig tidligt i tyverne ud i et omfattende projekt, der kan minde om Mallarmés drøm om at skrive 'Le Livre', og ligesom Mallarmés drøm forblev uindløst, fik Bachtin aldrig realiseret sit projekt. Han ville etablere intet mindre end en ny ' $ø \varnothing r s t e$ filosofi'. Indledningen til denne findes i form af det omkring firs sider lange fragment »Mod en handlingens filosofi «, og mod afslutningen af dette fragment påpeger Bachtin, at det videre værk skal bestå af fire dele (Act, p.54). Første del skal omhandle den ansvarlige handlens arkitektonik, og i »Mod en handlingens filosofi« findes de første ca. 20 sider af denne del (jvf. Act, pp.56ff). Anden del skal omhandle æstetisk aktivitet, og vi arbejder som nævnt med den tese, at »Forfatter og helt i æstetisk aktivitet « er et udkast til denne del. Tredje del skulle omhandle politikkens etik og fjerde del religionen. Bachtin fik formentlig aldrig skrevet de to sidste dele, og »Mod 
en handlingens filosofi « og »Forfatter og helt i æstetisk aktivitet « forbliver ufærdige og ugennemarbejdede fragmenter, der endvidere adskiller sig fra hinanden ved en markant forskellighed i sprogtone: det filosofiske, neologismefyldte og næsten heideggerianske sprog $\mathrm{i} » \operatorname{Mod}$ en handlingens filosofi« over for det mere tilgængelige og ligefremme sprog $\mathrm{i} »$ Forfatter og helt i æstetisk aktivitet«, som kun skæmmes af Bachtins fors $\emptyset \mathrm{g}$ på at integrere neologismerne fra »Mod en handlingens filosofi $\ll$.

At projektet ikke blev fuldført kan skyldes mange ting, men det er vores formodning, at den grundlæggende filosofiske, moralske og æstetiske tænkning, som er regulerende for både »Mod en handlingens filosofi « og »Forfatter og helt i æstetisk aktivitet «, er præget af en dyb indre modsigelse, der hindrer projektets indløsning. Dette viser sig ikke mindst i Bachtins tænkning af det arkitektoniske, denne centralkategori fra det tidlige forfatterskab. Og på sin vis er det netop som sådan - som mislykket projekt - at det er mest interessant, for herigennem afsløres i eminent grad de visioner, Bachtin arbejdede med, men som han først fik givet en sammenhængende form i den senere del af forfatterskabet.

\section{Bachtins handlingsteori: Mellem Kant og livsfilosofi}

Det altoverskyggende karaktertræk ved »Mod en handlingens filosofi« er den ambitiøse, men uimponerede og direkte tilgang til de store spørgsmål. Projektet gælder som bemærket intet mindre end etableringen af en ny 'første filosofi', og med lette håndbevægelser affejer Bachtin videnskabens, æstetikkens og etikkens mulighed for at danne grundlaget for en 'første filosofi' og lancerer sit eget bud - et bud, der endvidere indeholder hans forslag til en overvindelse af den krise, som hærger samtiden. Og som allerede disse præliminære bemærkninger afslører, så har »Mod en handlingens filosofi« en del ligheder med »Kunst og ansvarlighed «. Man genfinder en række af pointerne og de filosofiske grundfigurer, ligesom de to filosofiske strømninger: den kantianske, rationalistiske tradition og den livsfilosofiske, fornuftskritiske tradition, der i uudfoldet form kunne lokaliseres i »Kunst og ansvarlighed «, er strukturerende for »Mod en handlingens filosofi «. Men det sker langt mere grundigt, nuanceret og systematisk, og herved afsløres i høj grad Bachtins bestræbelser. Han søger med livsfilosofien i hånden at gennemføre en af-transcendentalisering af Kants og måske især Husserls filosofi ved at erstatte de transcendentalfilosofiske momenter i deres tænkning med det han kalder værens arkitektoniske elementer - momenter som netop ikke altid allerede er sat, men præcist sættes i og gennem den ansvarlige handling. Den fænomenologiske 
tilgang Bachtin udfolder vidner endvidere ikke mindst om hans inspiration fra Scheler, der ligeledes hentede livsfilosofiske elementer ind i det fænomenologiske projekt. Men hos begge er videnskabelighedsaspirationen langt fra afvist og hos Bachtin er det særligt tydeligt i denne tidlige periode - også selv om det er umuligt at overse, at »Mod en handlingens filosofi « har en ufærdig karakter, der bl.a. betyder at begreber som etik og moral, æstetik og kunst bruges uden stringens og vanskeliggør læsningen af det i forvejen ikke lettilgængelige skrift. $^{8}$

I »Mod en handlingens filosofi« reflekterer Bachtin under begrebet kulturverden de uddifferentierede og autonomiserede vidensområder: videnskab, æstetik og etik, og refleksionen sker med Kant i hånden. Både på den måde, at Bachtin vil bestemme de tre områders gyldighed og omfangslogiske status, selv om det altså primært gælder deres mulighed for at danne grundlag for en 'første filosofi', og på den måde, at Bachtin hævder, at kulturverdenens uddifferentierede områder generelt lader sig karakterisere ved, at de udvikler sig med en egen lovmæssighed og struktur, de har hver deres område, hvorindenfor de kan afgøre en doms gyldighed, afdække universelle sandheder osv. Men for Bachtin er det helt essentielt at pointere, at de kun fungerer på et abstrakt niveau. De beskæftiger sig kun med meningen i eller produktet af en handling, dvs. de beskæftiger sig kun med det aspekt ved handlingen, der lader sig abstrahere og generalisere.

Dette er baggrunden for, at Bachtin kalder kulturverdenens Værensforståelse for teoretisme, og i en intens tour de force lader han videnskaben, æstetikken og etikken passere revy i en kritisk diskussion - blot for at konkludere, at trods deres forskellighed kan ingen af dem ud fra deres egen tilgang til Væren få greb om det aktuelt levede liv. Videnskaben ser - i sin søgen efter universelle sandheder - slet og ret bort fra den konkrete historiske kontekst og det konkrete menneske; æstetikken kan kun - via kunsten - nærme sig det konkrete levende liv i dets fuldstændiggjorte, lukkede form, som ikke er det levede livs form; og etikken opstiller universelle normer, som forsøger at regulere handlingen udefra, hvorved den afslører en manglende forståelse for den aktuelt udførte handling. Og fordi ingen af områderne kan indreflektere livet i dets konkrethed afviser Bachtin deres mulighed for at kunne udgøre en egentlig 'første filosofi' - en 'første filosofi' må tage sit afsæt i det konkret levede liv.

Dette kan også formuleres således, at Bachtin med livsfilosofien i baglommen opvurderer livet, han sætter det konkret levede liv i centrum for sin tænkning og sammenfatter det under begrebet livsverden. Det betegner den verden, hvori vores konkrete handlinger udføres, hvor vi som konkrete, enkelte mennesker lever, skaber, tænker, dør mv., dvs. det er en verden, som i modsætning 
til kulturverdenen er karakteriseret ved det ikke-abstrakte, ikke-almene og de uigentagelige sandheder, der à la Nietzsches perspektivisme sætter hver deres unikke, ikke-universelle sandhed i verden. Dette betyder at Væren her forstås i al sin flygtighed og åbne begivenhedskarakter, sin historiskhed, éngangsmæssighed og uafsluttelighed - en forståelse Bachtin sammenfatter under centralbegrebet Varen-som-begivenhed, og som han knytter sammen med en overensstemmende forståelse af mennesket. Ifølge Bachtin møder mennesket både verden som givethed og - gennem dets aktive forholden sig til den - som projekt, som indløsningsstedet for livsudkast, mål og mening. Denne dobbelthed giver Bachtin anledning til at bestemme mennesket som ikke-sammenfaldende med sig selv, ikke forstået i negativ, melankolsk forstand som en indre splittelse, men forstået positivt som menneskets grundlæggende åbenhed og mulighed for udvikling, forandring mv. ${ }^{9}$ Og lad os tilføje allerede her, at disse formuleringer udgør den første del af den filosofiske antropologi, som skal forblive konstituerende gennem hele Bachtins forfatterskab, og at det er på dette grundlag, at han vil konstruere sin moralfilosofiske 'første filosofi'.

$\mathrm{Nu}$ er Bachtins projekt imidlertid ikke en fuldstændig afskrivning af kulturverdenen; han fremhæver, at for så vidt »som den abstrakt teoretisk selvregulerede [kultur]verden ... forbliver inden for sine egne grænser, er dens autonomi legitim og ukrænkelig « (Act, p.7), og således vil han ikke skrive under på livsfilosofiens videnskabsforskrækkelse og fornuftskritik. Dette hænger sammen med, at kulturverdenen ikke kun abstraherer meningen og indholdet ud af den konkrete handling, men også omvendt leverer mening og indhold til den konkrete handling. Det vil sige, at når vi handler konkret-ansvarligt er meningsindholdet $i$ denne handling hentet fra kulturverdenen. Kulturverdenen er således dét reservoir af potentiel mening og indhold, som skal aktualiseres i livsverdenens konkrete handlinger, og på denne måde tænker Bachtin en nødvendig sammenhæng mellem de to verdener.

Det er da også - som det ligeledes fremgik af »Kunst og ansvarlighed « - på baggrund af, at de to verdener er faldet fra hinanden, at Bachtin lokaliserer en krise i samtiden, »en ødelæggende ikke-sammensmeltning og ikke-gennemtrængen af kultur og liv« (Act, p.3), som på den ene side implicerer, at kulturverdenens rationalitet bliver forvandlet til en instrumentel fornuft, der er »blind og elementær« (Act, p.30), og på den anden side medfører, at livsverdenen bliver tømt for mening og værdi, den konkrete handling synker til et niveau »af elementær biologisk og $\varnothing$ konomisk motivation « (Act, p.55). Det gælder således primært moderniseringsprocessernes afkast af kulturelle forstyrrelser og kriser; Bachtin har på dette tidspunkt stort set ikke blik for de selvsamme processers afkast af sociale og økonomiske problemer - og hans 
bud på overvindelsen af denne krise tager som nævnt form af et forsøg på at etablere en ny 'første filosofi', en moralsk funderet filosofi om handlen.

I udfoldelsen af denne genkendes sporene fra Bachtins dobbelte inspirationskilder. Bachtin søger at udfører en 'kritik' i Kants ånd, dvs. han prøver at bestemme mulighedsbetingelserne, gyldigheden og rækkevidden af den moralske handling. Men inspirationen fra livsfilosofien er også tydelig. Selve påstanden om, at kulturverdenen ikke kan danne grundlaget for en 'første filosofi', da det kun er »inde fra den aktuelt udførte handling, som er éngangsmæssig, integreret og enhedslig i dens ansvarlighed, at vi kan finde en tilgang til den enhedslige og éngangs-mæssige Væren i dens konkrete aktualitet « (Act, p.28), er livsfilosofisk struktureret. Og Bachtins idé om, at alene orienteringen mod den aktuelt udførte handling kan danne grundlag for en moralfilosofisk 'første filosofi', hviler på livsfilosofiens grundlæggende forestillinger om at skabe en tænkning med virkning i livet, skabt på grundlag af det enkelte menneskes egne erfaringer i stedet for - som den tidligere katederfilosofiske tilgang - at sky ethvert mere konkret spørgsmål til eksistensen. Således kan man igen aflæse den dobbelte inspiration fra den rationalistiske filosofi og livsfilosofien hos Bachtin; han bruger den ene til at kritisere den anden med, og i »Mod en handlingens filosofi« er der stort set lige så mange udfald mod Kant som mod Nietzsche og Bergson. Derved forsøger han at tvinge dem ind i en kritisk dialog, hvor begge bidrager til hans eget projekt.

Bachtins moralfilosofiske afsæt er helt konsekvent, at der ikke findes nogen etiske normer, der er gyldige i sig selv eller universelt gældende, enhver handling har sit eget unikke sandhedsperspektiv, »men der er et moralsk subjectum med en bestemt struktur (ikke en psykologisk eller fysiologisk struktur, selvsagt), og det er ham vi bliver nødt til at stole på: Han vil vide, hvad der er mærket af det moralske burde og hvornår« (Act, p.6). Videre pointerer Bachtin, at det moralske subjectums struktur er en bestemt bevidsthedsholdning, og at han vil kortlægge denne fænomenologisk, dvs. han vil identificere de konstitutive momenter i den. Disse udsagn er interessante, ikke kun fordi de afslører en tydelig gæld til Husserl, der som bekendt forsøgte at gennemføre samme projekt i forbindelse med erkendelsen, men samtidig afslører de, at Bachtins moralfilosofiske projekt har en ren formal, indholdstom karakter. Dette sætter fokus på et blindt punkt eller en latent spænding i Bachtins fors $ø \mathrm{~g}$ på at etablere en moralfilosofi, som er en følge af hans dobbelte inspirationskilder: Han vil på én og samme gang fastholde det unikke, éngangs-mæssige og uigentagelige ved enhver konkret handlen i livsfilosofiens ånd, men samtidig $\emptyset$ nsker han at bestemme en række konstitutive momenter i denne handlen som altid må være til stede, hvis handlingen skal kvalificeres som moralsk og ansvarlig. Denne spænding præger i $\emptyset v r i g t$ hele Bachtins forfatterskab, men pa- 
radoksalt nok er det også i dette spændingsfelt, at en stor del af Bachtins styrke ligger gemt: Bachtin forsøger både i sin moral-, sprog- og romanteori at teoretisere og generalisere et felt, han selv karakteriserer som grundlæggende ikkegeneralisérbart.

I »Mod en handlingens filosofi« behandler Bachtin imidlertid ikke eksplicit dette spændingsfelt; han kaster sig i stedet ud i en bestemmelse af de konstitutive momenter i den ansvarlige handlen, og på kort begreb kan man sige, at den ansvarlige handlen, ifølge Bachtin, forener tre momenter: 1) et meningseller indholdsmoment; 2) et Varensmoment; og 3) et emotionelt-viljesmaessigt moment.

Meningsmomentet er det træk ved handlingen, hvor kulturverdenens reservoir af potentiel mening og indhold, af gyldige domme og videnskabelige indsigter og sandheder, aktualiseres og får konkret betydning i Væren - og hinsides denne aktualisering forbliver, som anført, både handlingen og kulturverdenen meningsløse. Varensmomentet konstituerer handlingens unikke éngangs-mæssighed, dvs. Værensmomentet betegner for Bachtin selve den konkrete, historiske faktualitet: Det speficikke rum, det bestemte tidspunkt og sted, de konkrete mennesker mv., der sætter den unikke, éngangs-mæssige situation, som handlingen finder sted i og ud fra. Dette forlener handlingen med en absolut uigentagelighed og unik kontekstsensitivitet. Og det emotioneltviljesmassige moment er det træk ved handlingen, hvor den aksiologiske investering finder sted: »Den aktive oplevelse af en oplevelse, den aktive tænkning af en tanke betyder ikke at være absolut indifferent over for den, betyder en bekræftelse af den på en emotionel-viljesmæssige måde. Aktuel handlingsudførende tænkning er en emotionel-viljesmæssig tænkning, en tænkning der intonerer, og denne intonation gennemtrænger på en essentiel måde alle momenterne af tankens indhold « (Act, p.34). Dvs. det er den emotionelt-viljesmæssige tone, der sammenbinder meningsmomentet og Værensmomentet $\mathrm{i}$ en enhed, og samtidig er det denne emotionelt-viljesmæssige tone, der relaterer selve handlingen til mig, lader handlingen fremstå som min handling.

At handlingen er specifikt relateret til mig, at det er min handling, er et centralt forhold ved Bachtins videre diskussion af sin moralfilosofi, og som det vil fremgå er hans begrundelse af den ansvarlige handlen parallel med eksistensfilosofien - og dermed også parallel med de filosofiske grundfigurer og pointer, der kunne identificeres $\mathrm{i} »$ Kunst og ansvarlighed «. Mennesket eksisterer, er kastet-ud i en konkret situation, altså i Væren-som-begivenhed, som Bachtin kalder det, og denne er som nævnt præget af en dobbelthed af det givne og af projekter. Dette reformuleres hos Bachtin som det-som-er og det-som-børblive, og ligesom bla. Sartre og Camus gør mennesket ansvarligt på baggrund af, at eksistensen går forud for essensen, er mennesket for Bachtin ansvarligt 
på grund af dets 'ikke-alibi'. 'Ikke-alibiet', altså den grundløshed som menneskets eksistens hviler på, implicerer et 'tvingende' burde til at vælge blandt de givne muligheder, og ved at vælge og dermed 'signere' valget som mit, kan jeg gennem den ansvarlige handlen realisere mig selv og sætte en mening og værdi i verden. Og dette er en ansvarlig menings- og værdisætten - i modsætning til, hvis jeg søger mig et 'alibi', altså søger at tildække tilværelsens grundløshed og kontingens gennem eksempelvis at anvende en videnskabelig eller æstetisk teori til at tildele verden en på forhånd givet mening, sammenhæng og værdi. Der ligger således en skelnen mellem den ansvarlige, egentlige og den uansvarlige, uegentlige eksistens hos Bachtin, og så langt er der næsten total konvergens mellem den tidlige, »eksistentialistiske « Heidegger og Sartre fra L'Être et le néant. Men mens Sartre på kantiansk manér gør det individuelle handlingsvalg til et valg på menneskehedens vegne, afviser Bachtin enhver universaliseringstendens: Han fastholder, at enhver ansvarlig handling har sin egen sandhed, sit eget uerstattelige perspektiv på verden, og at væren-som-begivenhed netop erholder sin unikhed gennem mangfoldigheden af enestående sandheder. Det gælder den nævnte tilstedeværelse af en nietzscheansk perspektivisme hos Bachtin.

Hermed har Bachtin lanceret den første markante del af sit moralfilosofiske projekt; men hvis han havde sluttet her, ville det unægteligt have været en mere end problematisk affære som moralfilosofi betragtet. Man kan sige, at Bachtin nærmere har leveret sit bud på, hvorledes moderniseringsprocessernes afkast af instrumentel fornuft, meningstab, menneskelig splittelse og mellemmenneskelig fremmedgørelse kan overvindes gennem en (re)integration af kultur- og livsverdenen, og dette kan nok give en idé om, hvad en meningsfuld handling vil sige, men næppe en moralsk, ansvarlig handling. Den formale definition af den ansvarlige handling, Bachtin giver, tømmer nærmest begrebet for betydning og lader ikke den ansvarlige handling beløbe sig til stort mere end min bekræftelse af mig selv i Væren uden hensyn til andre.

Bachtin slutter da heller ikke her, men indfører endnu en række konstituerende momenter i den ansvarlige, handle-udførende bevidsthed, det han kalder momenterne i dens konkrete arkitektonik, nemlig jeg-for-mig-selv, denanden-for-mig og jeg-for-den-anden. Disse momenter skulle ifølge planen være emnet for første del af Bachtins omfattende projekt, Ansvarlighedens arkitektonik, og vi skal her følge ham så langt som han nåede. 


\section{Arkitektoniske ansatser}

I denne første del (Act, p.56-75) vender Bachtin sig indledningsvist mod kunsten. Dette skyldes, at kunstens konkrethed og gennemtrængthed af emotionelt-viljesmæssighed kan hjælpe til en nærmere forståelse af den arkitektoniske struktur i den aktuelle Væren-som-begivenhed. Og på baggrund af en række bemærkninger om kunsten i almindelighed, som vi skal vende tilbage til senere, og en analyse af Pusjkins digt 'Adskillelsen' i særdeleshed, som vi ikke skal vende tilbage til,${ }^{10}$ får Bachtin installeret et æstetisk centralbegreb, nemlig opfattelsen af mennesket som et konkret vardicenter, dvs. mennesket som et unikt, uerstatteligt individ (jvf. Act, p.61ff.). At Bachtin netop bruger kunsten til dette, indikerer den grundlæggende vision: at kunsten bærer på en normativitet, at den udgør et sted hvorfra der kan hentes værdier og mening - en vision, der som nævnt løber gennem hele Bachtins forfatterskab fra »Kunst og ansvarlighed « til de sidste, ufærdige noter, og som i øvrigt minder om grundpointerne i Adornos og Heideggers æstetiske teorier. I denne sammenhæng anvender Bachtin installeringen af mennesket som værdicenter som afsæt for en diskussion af handlingens arkitektonik, og han lægger ud med at påpege, at der er en essentiel og fundamental arkitektonisk betydningsforskel mellem min egen éngangs-mæssige unikhed og unikheden af den anden, erfaringen af mig selv og erfaringen af den anden - vel at mærke set ud fra den handlendes konkrete værdisætning; i teoretismens tilgang er der ikke nogen forskel, f. eks. er døden teoretisk set ens for alle. Bachtin fremhæver endvidere, at mødet med den anden $»$ konstituerer en dyb ontologisk betydningsforskel inden for begivenheden i Væren« (Act, p.74), fordi der er tale om en mod-sætning mellem to fundamentalt forskellige værdicentre med hver deres emotionelt-viljesmæssige tone, hver deres værdisætten, perspektiv mv. på verden. Og dette bliver det centrale arkitektoniske princip i verden (jvf. Act, p.74).

Men Bachtin fremhæver samtidig, at den værdimæssige arkitektoniske deling af verden i jeg og den anden ikke blot er en tilfældig, færdig og lukket arkitektonik, jeg passivt er sat i, men en arkitektonik som skal realiseres gennem min ansvarlige handlen: »Det konkrete burde er et arkitektonisk burde: Burde aktualiserer ens unikke plads i éngangs-mæssig Væren-som-begivenhed. Og det er bestemt først og fremmest af mod-sætningen mellem jeg og den anden (Act, p.75). Dvs. sammen med de tre dele af den ansvarlige handling menings- eller indholdsmomentet, Værensmomentet og det emotionelt-viljesmæssige moment - optræder nu »den anden« som et altid allerede givet moment ved den ansvarlige handlen.

På dette sted afbrydes fragmentet desværre. Den egentlige gennemtænkning af den arkitektoniske modsætning mellem jeg og den anden mangler her, 
men findes, heldigvis, $i$ en rimeligt udfoldet udgave $i$ »Forfatter og helt $i$ æstetisk aktivitet «, hvor spørgsmålet imidlertid er æstetisk aktivitet og ikke moralsk handlen. Derfor mangler de moralske implikationer, Bachtin selv ville uddrage af mod-sætningen mellem jeg og den anden, men det er dog klart, at selv om bestemmelsen stadigvæk har en formal karakter, så medfører Bakhtins forståelse af mennesket som værdicenter et moralfilosofisk løft i hans tænkning. Den ansvarlige handling gælder ikke kun min bekræftelse af mit unikke selv, men gælder en samtidig bekræftelse af den andens lige så unikke tilstedevær, dvs. min bekræftelse af mig selv må ikke indebære en af-kræftelse (vold, nedvurdering, undertrykkelse mv.) af den anden. Denne opfattelse har selvsagt også betydning for Bachtins filosofiske antropologi - for som antydet er det præcist Bachtins filosofiske antropologi, der danner grundlag for hans moralfilosofi eller omvendt; man kan ikke skelne Bachtins filosofiske antropologi fra hans moralfilosofi, hans filosofiske antropologi er normativ i sin kerne.

Og konsekvensen af, at Bachtin installerer den anden ved siden af forståelsen af mennesket som et åbent, udviklende og forandrende individ, indskrevet i Væren-som-begivenheds ligeledes åbne, udviklende og forandrende forløb, er en grundlæggende moralsk menings- og værdisætten, som sætter det frie, lige møde mellem uerstattelige, ukrænkelige og unikke individer som betingelsen for moralsk, ansvarlig handlen - og som den absolutte værdi. Således finder vi allerede $\mathrm{i} » \operatorname{Mod}$ en handlingens filosofi $\ll$ de humanistiske forestillinger, der også ligger bag Bachtins senere storværker - Problemer i Dostojevskijs vark (1929/1963) og François Rabelais' vark og den folkelige kultur $i$ middelalderen og renassancen (1965) - og derfor er det ikke overraskende, at man også i disse værker, omend under andre begreber, genfinder en tænkning af væren-som-begivenhed, det manglende alibi i væren, den arkitektoniske treklang af jeg-for-mig-selv, den-anden-for-mig samt jeg-for-den-anden og endelig mennesket og helten i det litterære værk som værdicentrum. Det er kernen i Bachtins normative filosofiske antropologi, som han tænker den fra »Mod en handlingens filosofi« til de sidste notater i halvfjerdserne. I første omgang finder begreberne dog deres anvendelse $\mathrm{i} »$ Forfatter og helt $\mathrm{i}$ æstetisk aktivitet «, det vi antager skulle have udgjort anden del af Ansvarlighedens arkitektonik, og her forbindes de med en helt anden forståelse af det æstetiske end den Bachtin siden skulle nå frem til - og blive berømt for. 


\section{Den astetiske arkitektonik}

Bachtins eksplicitte mål i dette uafluttede skrift på omkring 225 sider er at undersøge forholdet mellem forfatter og helt, jeg og den anden, i den æstetiske aktivitet, og udfoldelsen af dette projekt sker i en til tider forvirrende blanding af tilgange til problemkomplekset: Bachtin reflekterer æstetik-filosofisk, udkaster svimlende historiske rids, kritiserer konkrete samtidige kunstopfattelser, og alt dette iblander han en række fænomenologiske udredninger, der kan minde om nogle af de analyser, bl.a. Sartre og Merleau-Ponty udfører senere, alle tre med baggrund i Husserls arbejde.

Men under dette omfangsrige net af sammenblandede tanker, ideer og perspektiver kan man ikke blot lokalisere en rimelig stringent systematik, men også de samme kantianske undertoner, som vi fandt $i$ »Mod en handlingens filosofi «: Bachtin vil have greb om selve det »principielle fundament « (jvf. $» \mathrm{AH} \ll, \mathrm{p} .4) \mathrm{i}$ forholdet mellem forfatter og helt - et fundament, der har principiel betydning ikke blot $\mathrm{i}$ kunstnerisk skaben og som strukturerings- og vurderingskriterium af kunst, men også for andre, ikke-æstetiske, områder. Dermed afhandler fragmentet fænomenet kunstskaben, men analyserer også kundskaben om jegets og den andens position i verden, og således kan det ses både som en videreføring og et bidrag til Bachtins fors $\varnothing \mathrm{g}$ på at skabe en 'første filosofi'. Opsporingen af fundamentet for forholdet mellem forfatter og helt finder da også sted med stadigt henblik på den videnskabelige og moralske aktivitet. Et centralt sted skriver Bachtin, at der inden for videnskaben ikke gives et enhedsligt subjekt, fordi - som det også fremgår af »Mod en handlingens filosofi « - det enkelte unikke individ er uden betydning set ud fra en videnskabelig vinkel. Det moralske subjekt er til gengæld et ikke-enhedsligt subjekt, fordi det som konkret, levende subjekt, indskrevet i Værens flygtige, éngangsmæssige og uafsluttede række af begivenheder, lever og handler i et nu der er rettet mod fremtiden, som indløsningsstedet for mål og mening. Det subjekt (dvs. helten) man møder i kunsten, produktet af den æstetiske aktivitet, er derimod et helt subjekt (jvf. » $\mathrm{AH} \ll, \mathrm{p} .83$ ). Bachtin skriver direkte, at den holdning forfatteren indtager over for helten er kendetegnet ved at være »en holdning til heltens helhed som menneske, en holdning som forener alle heltens erkendelsesmæssige-etiske bestemmelser og vurderinger og fuldender dem i form af en enhedslig og unik helhed, der er en konkret, intuitiv helhed, men også en meningshelhed $(» \mathrm{AH} \ll, p .5)$.

Med denne specificering af subjektets status har Bachtin fået indkredset og afgrænset det område, som han primært skal beskæftige sig med, og bredt formuleret er hans projekt $\mathrm{i}$ »Forfatter og helt i æstetisk aktivitet« altså at vise, hvorledes de arkitektoniske momenter, jeg og du, indgår i en særlig relation, 
når der er tale om æstetisk aktivitet. Det gælder et forsøg på at gennemtænke den normative filosofiske antropologi med dens dybe livsfilosofiske inspiration inden for æstetikkens område, og det er et område Bachtin tænker i forlængelse af den idealistiske eller nærmere romantiske filosofi, hvor kunstnerens skabende aktivitet er et eksemplarisk udtryk for menneskets aktivitet, og hvor det vellykkede kunstværk ses som en autonom helhed, en totalitet med mulige dannelseseffekter for læseren. Igen er Bachtins afsæt således den konkrete handling i Væren-som-begivenhed, omend det nu er den æstetiske handling, og da denne også reflekteres ved hjælp af en kritisk omgang med den idealistisk inspirerede, rationalistiske filosofi fra Kant til Husserl, genfindes samme inspirationskilder og videnskabelighedsaspirationer som $\mathrm{i} »$ Mod en handlingens filosofi«. Men mens målet i »Mod en handlingens filosofi«var identificeringen af de konstitutive momenter i den ansvarlige handlen, er målet nu bestemmelsen af det essentielle fundament for æstetisk handlen - og som antydet udpeges dette fundament som fuldendelsen af et andet subjekt, helten.

I »Forfatter og helt i æstetisk aktivitet« bliver det væsentligste spørgsmål derfor, hvordan denne fuldendelse af den anden overhovedet er mulig, og Bachtin installerer to æstetiske kategorier som svar på spørgsmålet. For det første det han kalder forfatterens synsoverskud, det vi skal kalde det astetiske blik, som udgør det essentielle princip i æstetiske aktivitet. Vi skal vende tilbage til den flere gange i det følgende, men det bør allerede her bemærkes, at vi har indført denne differentiering i Bachtins begrebsapparat for klarhedens skyld: 'synsoverskud' er, også ifølge Bachtin, et alment fænomenologisk grundvilkår i forholdet mellem jeg og den anden, og derfor må dette synsoverskud, før det kan fungere som en central æstetisk kategori, involvere en intentionalitet mod at ville fuldende den anden, og det er i denne forstand, vi taler om det æstetiske blik. For det andet indfører Bachtin den kategori, han kalder sympatetisk med-opleven - en kategori, som han installerer gennem et opgør med det han bredt betegner som ekspressiv æstetik (dvs. indfølingsæstetik) og impressiv æstetik (dvs. formal-stilistisk æstetik). Kategorien er en specifikation af det, han ellers omtaler som æstetisk komtemplation og indføling, ${ }^{11}$ og den dækker over et forhold, der er karakteriseret ved både med-opleven og distance, dvs. man med-oplever eller indlever sig i den anden, men opretholder stadig den distance som $\mathrm{g} \emptyset \mathrm{r}$, at den anden forbliver en anden. I $\emptyset$ vrigt et forhold, som Bachtin også mener karakteriserer moralsk handlen; forskellen er at den æstetiske aktivitet udmøntes i en fuldendelse af den anden, helten, mens moralsk handlen munder ud i en handling i forhold til den anden, hvor både jeget og den anden forbliver uafsluttede individer.

Efter installeringen af disse æstetiske kategorier gennemfører Bachtin en lang fænomenologisk præget argumentation for deres gyldighed, ikke mindst 
angående det æstetiske blik, og det er i denne argumentation, at det stringente i »Forfatter og helt i æstetisk aktivitet « afslører sig. For under det spindelvævsagtige net af tanker og perspektiver begynder Bachtin systematisk med en afdækning af, hvorledes jeg(-for-mig-selv) ikke er i stand til at opfatte mig selv som en konkret, hel krop i nogle specifikke omgivelser. Dernæst følger en afdækning af, hvorledes jeg ikke er i stand til at opfatte min egen »sjæl«, min erfaringsverden, som en helhed. Og sidst men ikke mindst som følge af de to første områder, hvorledes jeg ikke er i stand til at se mig selv som en meningshelhed - og hele denne gennemgang suppleres af modsætningen, nemlig den andens, forfatterens, mulighed for at fuldende mig som en helhed.

Bachtin indleder altså med en afdækning af, hvorledes jeg(-for-mig-selv) ikke kan opfatte mig selv som krop i nogle specifikke omgivelser, og han tager afsæt i den simple grunderfaring, at man ikke kan erfare sin egen ydre fremtrædelse, sin krops ydre grænser og sine egne ydre handlinger, fordi »mit eget ydre ikke er del af den konkrete, aktuelle horisont i mit synsfelt... Mit eget ydre (...) er erfaret af mig inde fra mig selv« (»AH«, p.27-28). Jeg selv har kun adgang til den såkaldt indre krop, dvs. »min krop i min selvbevidsthed $«(» \mathrm{AH} \ll, \mathrm{p} .47)$. Denne påstand underbygger Bachtin gennem en lang række fænomenologiske analyser og manøvrer, f.eks. viser han, hvorledes vi er afskåret fra at få et fuldt og sandt billede ved hjælp af vores egen forestillingskraft, i drømme, i spejle, på fotografier mv., han viser, hvorledes vi ikke kan erfare vores krops ydre grænser, dvs. vores placering i en omverden, fordi omverden altid optræder i vores selvbevidsthed som vores horisont, og han påpeger, at det også kun er inde fra vores egen selvbevidsthed og horisont, at vi oplever vores egne handlinger som udtryk for intentionale, målrettede og meningsgivende handlinger og ikke som handlinger indskrevet i tids- og rumlige koordinater.

De mange analyser og beskrivelser leder frem til Bachtins diskussion af kroppen-som-helhed, samlebetegnelsen for de tre afhandlede områder (ydre fremtrædelse, ydre grænser og ydre handlinger). I denne diskussion er det kroppen som værdi, der interesserer Bachtin, og hans grundtanke er, at vi ikke kan erfare vores egen 'ydre krop' (vores fremtrædelse, handlinger mv.; jvf. »AH«, p.35) som en værdi, hvilket nødvendiggør 'den anden': Han kan konkret se mere af os end vi selv er i stand til. Den anden har et synsoverskud, og han sætter muligheden for, at vores krop kan erfares som værdi - en pointe, Bachtin i øvrigt forbereder via en af sine meget sjældne omtaler af barndommen, der beskriver, hvorledes moderens kærlighed til barnet lader barnet erfare sin egen krop som værdi - og konklusionen bliver, at »kroppen er ikke noget selvtilstrækkeligt: den behøver den anden, behøver hans anerkendelse og formgivende aktivitet $«(» \mathrm{AH} \ll, p .51)$. 
Dermed har Bachtin etableret et udvekslingssystem mellem 'jeg' og 'den anden', hvor vi gensidigt sætter hinanden som værdier (qua krop), og som bemærket tidligere udgør dette udvekslingssystem også grundlaget for Bachtins normative filosofiske antropologi. Der er tale om en direkte, men udfoldet gentagelse af en konstituerende grundfigur, som hviler på forestillingen om vores arkitektoniske struktur, det burde som sætter den gensidige anerkendelse af værdigivning mellem jeg og den anden. I $»$ Forfatter og helt i æstetisk aktivitet« er den væsentlige pointe imidlertid, at synsoverskuddet qua det æstetiske blik udgør det første overskridende moment i forholdet mellem forfatter og helt: I og med at forfatteren kan se mere af helten og sætte hans fremtræden som værdi, besidder han muligheden for at fuldende helten æstetisk. Og det er - som ligeledes bemærket - netop denne fuldendelse, der kendetegner det æstetiske.

I Bachtins diskussion af det temporelle område, hvor undersøgelsen ikke gælder kroppen, men hvad Bachtin lidt altmodisch kalder 'sjælen', sigter han mod samme hovedpointe. Bachtin skriver selv, at »ligesom den rumlige form af et menneskes ydre eksistens udvikles den æstetisk gyldige tidslige form af hans indre liv fra overskuddet indlejret i mit tidslige syn på en anden sjæl«, hvor overskuddets overskridende momenter først og fremmest er de »tidslige grænser: begyndelsen og slutningen på et liv, som ikke er givet for en konkret selvbevidsthed« (» $\mathrm{AH} \ll, p .103)$. Og i den videre diskussion følger Bachtin den klassiske tyske filosofi og indfører skellet mellem ånden og sjælen. Ånden er så at sige jeg-for-mig-selv's bevidsthed, der udgør en aktiv del af mit konkrete liv, mine oplevelser, handlinger osv., således som de er udfoldet i min konkrete leven i Væren-som-begivenhed. Her er den centrale erkendelse, som i »Mod en handlingens filosofi «, at når jeg gebærder mig i verden, møder jeg verden som et projekt, jeg lever i en rettethed mod fremtiden som indløsningsstedet af mål og mening. Og Bachtin udfører også i denne sammenhæng en række fænomenologisk prægede analyser, der fungerer som et godt supplement til de mere overordnede filosofiske gennemgange $i » M o d$ en handlingens filosofi«, idet de uddyber, hvorledes vores konkrete liv udfolder sig.

Sjælen, skriver Bachtin, »er et billede af totaliteten af alt, der har været faktisk oplevet - af alt der er nærværende i sjælen i tidens dimension« (» $\mathrm{AH}$, p.110), dvs. sjælen udgør vores samlede erfaringsverden, således som den er blevet dannet fra vores fødsel til vores død. Det er dog væsentligt at fastholde, at når vi erfarer - $\mathrm{i}$ ånden, så at sige, altså erfarer i vores konkrete leven - så erfarer vi ikke selve erfaringen: Vi er i erfaringen og kan ikke undslippe denne selvbevidsthedens tryllekreds. Modsat med sjælen: Den er så at sige stedet, hvor erfaringen bundfælder sig hinsides konkrete mål, ønsker og mening, men som sådan er den usynlig for os selv - og ikke overraskende skriver Bachtin, 
at sjælen er en gave som gives af den anden (jvf. » $\mathrm{AH} «$, p.132). Selve denne formulering af sjælen skal pege på den samme pointe, som det var tilfældet $\mathrm{i}$ forbindelse med kroppen, nemlig at den anden har et synsoverskud, her forstået i overført betydning, og når dette behæftes med æstetiske briller muliggøres en fuldendelse - af sjælen, selvsagt; ånden kan aldrig fuldendes.

Hermed har Bachtin vist, hvorledes den anden har et synsoverskud, rumligt og tidsligt, der overskrider vores eget mulige syn på os selv, og disse overskridende momenter er ikke blot mulighedsbetingelsen for at vi gensidigt kan sætte hinanden som værdier i filosofisk antropologisk forstand, men samtidig i form af det æstetiske blik mulighedsbetingelsen for at en forfatter kan skabe en fuldendelse af helten og dermed et kunstværk. Og disse forhold understreges netop af det sidste aspekt, Bachtin diskuterer i forbindelse med den æstetiske aktivitet, nemlig helten henholdsvis forfatteren (/kontemplatoren) som meningshelhed. Helten udgør en meningshelhed, når hans horisont og betydningen af enhver bestanddel, enhver handling, ethvert objekt mv. inden for denne horisont fremstår som en meningsfuld helhed, altså når vi forstår verden set med heltens $\varnothing j n e$. Forfatteren (/kontemplatoren), derimod, udgør en meningshelhed, når alle disse bestanddele bliver til karakteristika ved helten som helhed, når de får en bestemmende og begrænsende betydning i relation til helten, altså når de tjener til at afgrænse helten og placere ham i nogle omgivelser, således at der præsenteres et sammenhængende, fuldendt billede af et liv som helhed (jvf. »AH«, p.174).

På denne måde har Bachtin fået gennemført sin argumentation for, hvorledes synsoverskuddet qua æstetisk blik muliggør - som det 'essentielle fundament' - den æstetiske aktivitet, der munder ud i en meningshelhed. Men inden fragmentet »Forfatter og helt i æstetisk aktivitet « går helt i opløsning diskuterer Bachtin en række konsekvenser af denne opfattelse, hvor særligt to tiltrækker sig opmærksomhed.

Først og fremmest viser diskussionens litteraturhistoriske del, at selv om Bachtin lader sin fremstilling styre af det principielle og formelle forhold mellem forfatter og helt, så har han en klar sans for de idéhistoriske og historiske forholds betydning for den litterære udvikling. Dette er interessant, dels fordi det rokker ved den etablerede konsensus om, at Bachtin først senere i sit forfatterskab beskæftiger sig med litteraturhistoriens udvikling, dels fordi denne historiske refleksion bliver ført op til modernismen, hvor det bliver klart, at der i det moderne - fra Dostojevskij og frem - opstår alvorlige problemer i forholdet mellem forfatter og helt. I det moderne bliver det vanskeligt for forfatteren at opnå et synsoverskud i forhold til helten; det gælder igen moderniseringsprocessernes afkast af meningstab, menneskelig og mellemmenneskelig splittelse og fremmedgørelse, og da Bachtin præcist har etableret dette 
synsoverskud, dette æstetiske blik, som muligheden for fuldendelse og dermed muligheden for et vellykket kunstværk, så bliver hans kritik af den moderne kunst, herunder altså også Dostojevskij, meget hård og negativ.

Den entydige opvurdering af det vellykkede kunstværk, hvor vellykketheden er betinget af, at helten er blevet fuldendt til en meningshelhed, kommer også frem i Bachtins privilegering af 'karakteren' og til en vis udstrækning 'typen', forstået som litteraturteoretiske kategorier. Fordi netop her respekteres heltens grænser i det ydre og det indre samt grænserne mellem forfatter og helt, dvs. helten kan fremstilles som en helhed, hvorved man får svaret på spørgsmålet: »hvem er han?«(»AH«, p.174) - en pointe Bachtin fremhæver med et imponerende vue ud over litteraturhistorien fra Plutark til Pusjkin. Det væsentlige er imidlertid, at baggrunden for, at Bachtin opvurderer 'karakteren' og den æstetiske fuldendelse i det hele taget er, at det således bliver muligt i kunsten at opleve og erfare 'det hele menneske' (helten), det værdisatte, individualiserede menneske. Der er her tale om, at Bachtins installering af værens arkitektoniske adskillelse mellem jeg og den anden som et moralsk 'burde', der implicerer at vi gensidigt sætter hinanden som værdier og anerkender hinanden som individuelle personer med hver vores syn på verden - at dette arkitektoniske 'burde' netop realiseres i kunstværket, og derfor kan Bachtin parallelt med den romantiske æstetik ikke blot se forfatterens aktivitet som eksemplarisk for den menneskelige aktivitet, men også se et positivt dannelsesaspekt i kunstens helhedsdannelse. Det gælder selve den normativitet, Bachtin tilskriver kunsten, og som vi kunne identificere allerede $i »$ Kunst og ansvarlighed « og som $\mathrm{i}$ »Mod en handlingens filosofi « gjorde, at kunsten kunne fungere som et af de mulige meningsmomenter i vores ansvarlige handlen. I sig selv er dette ikke problematisk, men det peger alligevel på den indre modsigelse, som efter vores opfattelse får Ansvarlighedens arkitektonik til at bryde sammen.

Modsigelsen opstår mellem på den ene side Bachtins normative filosofiske antropologi, hvor han søger at bestemme menneskene som uerstattelige og ukrænkelige subjekter, der i sig selv er åbne og forandrende, og indtræder i Væren-som-begivenheds ligeledes åbne og forandrende forløb som ligeværdige subjekter, dvs. de indtræder i en subjekt-subjekt relation, og på den anden side hans idé om kunst(skaben), hvor helten sættes som passivt objekt for forfatterens skabende aktivitet og tvinges ind i en fuldendt, lukket helhed. Således hviler kunst(skaben) i de tidlige tekster grundlæggende på en subjekt-objekt-relation, som indebærer en fundamental krænkelse af den anden, helten, hvis åbenhed og mulighed for forandring undertrykkes af den æstetiske forms benhårde greb.

Den normativitet, Bachtin tildeler kunsten, går således mod hans egne normative forestillinger, da det er vanskeligt at se, hvorledes den æstetiske forms 
kvælertag på helten kan danne et positivt sæt af værdier, som kan udgøre et grundlag for moralsk handlen. Det er da også præcis her, at man finder den radikale udvikling hos Bachtin: I Problemer i Dostojevskijs vark (1929) foretager Bachtin en total omvurdering af sine æstetiske værdier, nu er idealet fremstillingen af helten, som et åbent, uafslutteligt individ, der indgår i dialogiske, ikke-hierarkiserede subjekt-subjekt relationer, ikke blot med de andre helte, men også med forfatteren, og selv får lov til at svare på »hvem er jeg «. Modbilledet bliver den monologiske roman med dens hierarkiserede subjektobjekt-logik, som lader forfatteren overmande sin helt og svare på »hvem er han $\ll^{12}-$ ikke uligt Bachtins position i »Forfatter og helt i æstetisk aktivitet«. Til denne kovending hører også, at Bachtin helt vender sig fra sin tale om 'synsoverskud', der trods alt har undertoner af beherskelse og undertrykkelse, til at tale om hørelsen, det er den aktive lytten til den andens tale, som bliver den væsentlige metafor for kunst(skaben).

Det lykkes ikke for Bachtin i den tidlige periode at foretage denne vending, og derfor er også det sidste skrift fra denne periode, »Problemet om indhold, form og materiale i verbal kunst«, præget af de samme æstetiske idealer, som ligger til grund for »Forfatter og helt i æstetisk aktivitet«. Men man kan ikke undgå at bemærke en række forskydninger, ikke kun i den eksplicitte refleksion over sproget, men også i selve tænkningen af det æstetiske, som peger direkte frem mod Bachtins videre udvikling, og det er på denne baggrund, at vi indledningsvist kaldte skriftet for en overgangstekst.

\section{Det cestetiske objekt}

»Problemet om indhold, form og materiale i verbal kunst « og den lille artikel »Kunst og ansvarlighed « er de eneste fuldendte tekster fra perioden. Det var planlagt, at »Problemet $i$ indhold... « skulle trykkes som essay i et litterært tidsskrift, men inden da blev forlaget lukket af den offentlige myndighed og essayet først udgivet mange år senere. Teksten fylder godt 60 sider og endnu en gang er det et af de store spørgsmål, Bachtin tager op. Han vil skabe intet mindre end en systematisk, filosofisk æstetik, hvor han søger at svare på såvel kunstens, den kunstneriske skabens og kunsterfaringens væsen som betydningen af kunst i menneskets tilværelse, og dette projekt udfolder han i et specifikt opgør med den samtidige russiske formalisme, i et ligefremt, tilgængeligt sprog, som skal forblive Bachtins varemærke igennem resten af forfatterskabet.

Allerede dette afsæt indikerer en af forskydningerne fra »Forfatter og helt i æstetisk aktivitet«, idet perspektivet radikalt bredes ud. Bachtin tager i »Pro- 
blemet om indhold...« fat om emner, som han kun strejfer $\mathrm{i} \gg$ Forfatter og helt i æstetisk aktivitet«, mens forholdet mellem forfatter og helt kun strejfes i »Problemet om indhold...«- omend det får denne prægnante og sigende formulering med på vejen: »Denne [æstetiske] aktivitet (organiseret indefra) af kunstnerens personlighed, afviger essentielt fra heltens passive personlighed (organiseret udefra), altså fra mennesket gjort til genstand for det kunstneriske syn, bestemt i krop og sjæl« (»PC«, p.316). Men trods denne markante formulering, så er der næppe tvivl om, at Bachtin havde fornemmet det indsnævrede og problematiske i sin tilgang til dette spørgsmål. Dette viser sig i eminent grad ved, at han ikke som i »Forfatter og helt i æstetisk aktivitet« lader forholdet mellem forfatter og helt - sammen med ideerne om synsoverskud og fuldendelsen - udgøre det principielle fundament for det æstetiskes særegenhed til forskel fra videnskabelig og moralsk aktivitet. Bachtin nævner i » Problemet om indhold... « alle disse forhold, og de har stadig en vis betydning i argumentationens logik, men han indfører også en helt ny definition af det æstetiskes særegenhed, nemlig det cestetiske objekt. I konsekvent forlængelse heraf forstår han ikke synsoverskuddet, men den sympatetiske med-opleven, denne kobling af indlevelse og distance, som grundbetingelsen for en kontemplation af kunsten, altså både skaben og reception af kunst. Den centrale forskydning fra »Forfatter og helt i æstetisk aktivitet« til » Problemet om indhold...« ligger således i, at det æstetiskes særegenhed ikke længere hænges op på forholdet mellem forfatter og helt, men på det æstetiske objekt og de konsekvenser dette indebærer, og derfor skal vi primært indkredse Bachtins forståelse af det æstetiske objekt.

Bachtins forsøg på at forstå og definere det æstetiske objekt er som næunt specifikt rettet mod den samtidige russiske formalisme og dens grundlæggende lingvistiske, autonomiorienterede og indholdsfjendtlige tilgang til litteraturen. Ganske vist deler Bachtin målsætningen om at etablere litteraturstudiet som en selvstændig videnskabelig disciplin med formalisterne, og ligesom formalisterne lægger Bachtin heller ikke fingrene imellem i sin karakteristik af den foregående standard, der var et skalkeskjul for »forskellige former for videnskabelig set uansvarlig snak med fordring om dybsindighed «, en »æsteticeret, halv-videnskabelig tankegang, der sommetider ved en misforståelse kaldte sig selv for filosofisk « (»PC«, p.258). I forhold til denne standard tager formalisterne et kæmpe skridt fremad, men Bachtin er af den opfattelse, at de ikke har en tilfredsstillende filosofisk og æstetisk overbygning på deres analytiske praksis, deres »material æstetik «, som han kalder den. ${ }^{13}$ Og det er op imod denne uindløste æstetik, at Bachtin leverer sit eget forslag, hvis kerne altså er hans idé om det æstetiske objekt, defineret ud fra en bestemt forståelse af indholdet, materialet og formen i et kunstværk. 
I et kunstværk lader indholdet sig, ifølge Bachtin, på traditionel vis forstå som »den virkelighed af erkendelse og etisk handlen, som indgår .. i det æstetiske objekt og som er underkastet en konkret, intuitiv enhed, individuation, konkretisering, isolering og fuldendelse, dvs. en proces af omfattende og forståelsesskabende æstetisk formning ved hjælp af et særligt materiale « (»PC«, p.281). Dvs. selve indholdet i et æstetisk objekt er en given virkelighedsbegivenhed med erkendelsesmæssige, etiske, aksiologiske momenter indlejret $\mathrm{i}$ sig, en del af Væren-som-begivenhed, og Bachtins insisteren på indholdets betydning understreger på den ene side hans klare afstandstagen til de tidlige russiske formalisters (delvise) udradering af litteraturens indholdsmæssige aspekter, og på den anden side markerer indholdsfokuseringen en udvidelse i forhold til »Forfatter og helt i æstetisk aktivitet«, hvor al kunst syntes begrænset til forholdet mellem forfatter og helt.

I definitionen af indholdet nævner Bachtin også materialet, dvs. sproget, det aspekt han nærmest havde set bort fra indtil nu, og i hans diskussion af sprogets betydning er han på fuld konfrontationskurs med de russiske formalister. Bachtin hævder, at de russiske formalister alene forstår materialet ud fra en snæver, lingvistisk sprogdefinition, og at de i forlængelse heraf udelukkende forstår form som formet materiale. Bachtin argumenterer derimod for, at sproget $-\mathrm{i}$ lingvistisk forstand - kun er et teknisk moment som overskrides i skabelsesprocessen. Kunstneren frigør sig fra sproget i dets konkret lingvistiske betydning ved at perfektionere det immanent, tvinge det til at gå hinsides sig selv: »Poesien er ingen undtagelse fra den generelle læresætning, der gælder for alle kunstarterne: kunstnerisk skabelse, bestemt i forhold til dets materiale, udg $\phi r$ en overskridelse af dette materiale« (»PC«, p.294). Formuleringen om, at kunstnerisk skaben betyder en overskridelse af materialet, er i en vis forstand selve kernen i hele dette essay og udtrykker en af Bachtins første, omend mere usystematiske, formuleringer af det opgør med lingvistikken, der bliver gennemgående i resten af forfatterskabet og senere udmønter sig i hans begreb om metalingvistikken.

For at forstå hvor Bachtin vil hen med denne tanke om overskridelsen af sproget som lingvistikken opfatter det, må vi inddrage det tredje og sidste aspekt, nemlig formen. Bachtin indfører her en distinktion mellem den arkitektoniske form og den kompositionelle form - en distinktion, som de russiske formalister ikke kan foretage på baggrund af deres lingvistiske tilgang til litteraturen. Formalisterne kan kun tilnærme sig den kompositionelle form, dvs. typisk genreformerne drama, epik og lyrik samt forholdene omkring akter, kapitler, vers, strofer mv. I modsætning hertil er de arkitektoniske former defineret som den æstetiske individualisering og fuldendelse af en person, en begivenhed mv., og hermed bliver det klart, at de arkitektoniske former er spe- 
cifikt relateret til indholdet. Det er indholdet, der formes gennem de arkitektoniske former (individualiseres, fuldendes), mens de kompositionelle former er underordnet denne formningsproces, selv om det er dem, der i sidste instans opdeler og på konkret niveau sætter selve kunstværkets rammer. Det helt centrale - og det der markant adskiller Bachtin fra de russiske formalister - er imidlertid, at Bachtin lader selve denne arkitektoniske formning være udtryk for forfatterens - og siden læserens - specifikke emotionelt-viljesmæssige og aksiologiske investering i indholdet, deres sympatetiske med-opleven - den samme aktivitet, som betyder en overskridelse af sproget i snæver lingvistisk betydning. Med Bachtins ord: »Sålænge vi simpelthen ser eller hører noget, forstår vi ikke den kunstneriske form; man må gøre det, som er set eller hørt eller udtrykt til et udtryk for ens egen aktive, aksiologiske forhold, man må indgå som en skaber i det som er set, hørt eller udtrykt (...). [Dvs. formen er] udtryk for det aktive, aksiologiske forhold hos forfatter-skaberen og hos læseren (som med-skaber formen) til indholdet « (»PC«, p.305-306). Det er kort sagt umuligt at forstå et kunstværk uden et konkret engagement.

Hermed har Bachtin leveret sin definition af det æstetiske objekt: Det (in casu litterære) æstetiske objekt er et formet indhold i et materiale, som er løsrevet fra dets snævre lingvistiske definition og indgår som integreret del af kunstværkets æstetiske, moralske og erkendelsesmæssige helhed af kompositionelle og - via den sympatetiske med-opleven - arkitektoniske former. Og med denne definition mener Bachtin, at han har lagt grunden til, at æstetikken (og især litteraturvidenskaben) kan forvandles til en selvstændig disciplin med et eget studieobjekt.

Det kan naturligvis være vanskeligt at se, hvordan man kan basere et videnskabeligt studie på en forståelse af det æstetiske, som ikke mindst er hængt op på forfatterens og læserens aktive, sympatetiske med-opleven i kunstværket omend projektet på sin vis kan minde om receptionsæstetikken. Men vi må afholde os fra denne diskussion, og i stedet vil vi kort opholde os ved de konsekvenser og perspektiver, som ligger gemt i ideen om det æstetiske objekt samt dets betydning i Bachtins udvikling.

Og i første omgang er det bemærkelsesværdigt, at Bachtins definition af det æstetiske objekt ligner en reformulering af de tre momenter, han udpegede som konstitutive ved den moralske, ansvarlige handlen $\mathrm{i}$ »Mod en handlingens filosofi« - Værensmomentet, meningsmomentet og det emotionelt-viljesmæssige moment - og det er da også heri, at man finder baggrunden for Bachtins tydelige opvurdering af den sympatetiske med-opleven frem for synsoverskuddet. Han forsøger i »Problemet om indhold...« helt entydigt at gøre kunstskaben og kunstreception til en moralsk handling, en unik aktivitet indskrevet i Væren-som-begivenheds åbne, éngangs-mæssige og uafsluttelige for- 
løb. I forlængelse af dette er det naturligvis også interessant at bemærke, at den samme treklang senere gentages i Bachtins sprogfilosofiske metalingvistik, denne gang reformuleret som kontekst, mening og intonation som mulighedsbetingelsen for at forstå en ytrings betydning; ligesom det kan læses som en foregribelse af Bachtins senere fokusering på det aktive, dialogiske forhold mellem forfatter, personer og læsere i konstruktionen af den dialogiske polyfoni, hvor den aktive eller svarende forståelse bliver omdrejningsaksen.

I anden omgang er det imidlertid væsentligt at fremhæve, at Bachtin på baggrund af sin definition af det æstetiske objekt også får formuleret kunstens betydning i den menneskelige tilværelse, og således udgør det æstetiske objekt på sin vis svaret på alle den filosofiske æstetiks spørgsmål og problemer. Han skriver et centralt sted: »Jeg bliver aktiv i formen, og gennem formen indtager jeg en aksiologisk position uden for indholdet som erkendelsesmaessig-etisk rettethed, og dette muligg ør for første gang fuldendelsen « (»PC«, p.306). Dvs. det er positionen som den engagerede, med-oplevende omend distancerede anden, der muligg $\varnothing r$ denne fuldendelse - en interessant skæv formulering i forhold til tankerne $\mathrm{i} »$ Forfatter og helt i æstetisk aktivitet«. Og selv om pointen bliver den samme, nemlig at mennesket i denne aktive oplevelse/skabelse af fuldendelsen har mulighed for at opleve sig selv som et helt menneske den »kunstneriske kreative form .. giver en form til det hele menneske « (»PC «, p.317), hvor vi genfinder det romantisk inspirerede dannelsesideal, der lader kunsterfaringen blive grundlaget for, at mennesket kan træde ud af sin splittede eksistens - så er det klart, at Bachtin har vanskeligt ved at opretholde denne idé. Tyngdepunktsforskydningen går fra synsoverskuddet til den sympatetisk med-opleven, fra helhedsoplevelsen til den aktiv deltagelse og fra fuldendelsen til det æstetiske objekt. Alt dette peger på, at Bachtin i » Problemet om indhold... « har trukket æstetikken langt tættere på sin egen normative filosofiske antropologi, selv om den normativitet, han tilskriver kunsten, altså stadigvæk er knyttet til de forestillinger om helhedsdannelse, der sætter den hierarkiske subjekt-objekt-relation og dermed modsiger Bachtins egne visioner, hvor menneskets væren i verden som et moralsk handlende individ kan hente værdier og mening fra kunstens normative rum. Og som tidligere bemærket er det først i Bachtins efterfølgende udgivelse, Problemer i Dostojevskijs vark, at denne vision om væren, moral og æstetik finder en adækvat form. 


\section{Kontinuitet, brud og perspektiver}

Der er mange tråde man kunne tage op i en afrundende vurdering af de tekster, vi har behandlet her. Undervejs har vi kun flygtigt berørt Bachtins romantisk inspirerede tanke om at se forfatterens aktivitet som paradigme på den menneskelige aktivitet; vi er i en vis forstand alle forfattere til vores eget liv; og som Holquist og Clark antyder er dette muligvis den kontinuitetsskabende faktor mellem den tidlige, handlingsteoretiske Bachtin og sene, sprogfilosofiske Bachtin. ${ }^{14}$ Ligeledes har vi kun strejfet det omfattende spørgsmål om den tidlige Bachtins tænkning af fuldendelsen, helheden og autonomien, selve totalitetsæstetikken, over for den senere forestilling om en uafsluttelighedens æstetik, som forbinder sig lydefrit med Bachtins moralske og filosofisk antropologiske forestillinger. Og vi har slet og ret ikke berørt Bachtins tydelige religiøse interesser, som i kombination med hans eksistentialistiske prægning ikke blot peger på den russiske, ortodokse tro, men også gør Kierkegaard til en endnu mere oplagt tænker at sammenligne Bachtin med. ${ }^{15}$

Endnu flere halvt eller helt uberørte områder kunne opremses, men som vi allerede indledningsvis gjorde opmærksom på, har vores tanke været at lokalisere den linje eller intonation, som løber gennem hele forfatterskabet, men står frem med særlig prægnans i de tidlige skrifter, nemlig den dybe moralskeksistentielle accent og - sammenhængende med den - Bachtins normative filosofiske antropologi. Bachtin slår fast, at enhver forestilling om neutralitet er udelukket: Den rationalistiske eller idealistiske fremmed- eller ligegyldighed over for en handlings eller tankes konsekvens er et afgørende ankepunkt for Bachtin. ${ }^{16}$ Der findes ingen ren fornuft, ingen historisk ånd, ingen abstrakte ideer, der ikke bør tænkes ind i en reel verdenssammenhæng og ind i relationen jeg og du - forhold, der senere i hans karriere omformes til, at der ikke findes neutrale ord, ingen neutral litterær form. Alt i denne verden er skabt af konkrete jeg'er og du'er med essentielle ansvarsmomenter forbundet til hver eneste form for handling.

Og selv om de opdagelser, Bachtin nåede frem til i disse tidlige tekster, og som han gentog, modificerede eller omformede til beslægtede temaer gennem resten af sit liv, på mange måder er forholdsvis enkle, grænsende til det banale: Vi har intet alibi i livet; jeg er kun i kraft af den anden; tid, rum og mening er de altgennemtrængende koordinater i menneskets liv; kunsten og livet kan kun forstås i kraft af en vurderende forståelse osv. - selv om disse opdagelser er enkle, så synes Bachtins særegne styrke at opstå af den stædighed, hvormed han formåede at gentage sine sandheder i nye sammenhænge igen og igen i 50 år, uanset om emnet var filosofi, æstetik, litteraturteori eller kulturteori. Således udkaster den første lille tekst, »Kunst og ansvarlighed «, de to 
poler i et langt livs arbejdsunivers - den bærer på nogle grundlæggende visioner, ikke mindst om menneskets væren i verden som et moralsk, eksistentielt og værdiladet anliggende (Bachtins normative filosofiske antropologi), og om kunsten som et sted, hvorfra der kan hentes værdier, mening og sandhed (Bachtins idé om kunstens normativitet); de to visioner som forblev essentielle gennem hele Bachtins forfatterskab.

Men samtidig med at vi har villet pointere kontinuiteten i Bachtins forfatterskab, har vi villet fremhæve det, vi anser for det eneste radikale brud i Bachtins udvikling, hans kopernikanske vending eller teoretiske Big Bang, som finder sted i hans bog om Dostojevskij fra 1929. Denne sætter grænsen for de tidlige tekster, lader dem fremstå som en relativ selvstændig del i Bachtins collageagtige forfatterskab, selv om grænsen hverken må over- eller undervurderes, især må »Problemet om indhold...« læses som en uomgåelig overgangstekst. De ovennævnte temaer forbliver centrale gennem hele forfatterskabet, men med Problemer i Dostojevskijs verk foretager Bachtin sammen med resten af det 20. århundredes filosoffer sin »lingvistiske vending «, og hermed kaster han fortøjningerne til den kartesianske fortid og sætter kurs mod en materialistisk, dialogbaseret tænkning, der åbner op for hans originale nytænkning af sproget, æstetikken og kulturen.

Dette betyder også, at vi i modsætning til de kritikere, der i Bachtins udvikling udelukkende ser brud og inkonsistenser ud fra en given forudsat kerne (Todorov), samt de kritikere, der i hver eneste Bachtinlinie ser et grundlæggende kim udfolde sig (Holquist/Clark), vil plædere for en dynamisk forståelse af Bachtins udvikling. En sådan forståelse kan forklare, hvordan den indre modsigelse i Bachtins tænkning af liv og kunst i den tidlige periode peger på et udviklende element. Modsigelsen betinger forandringen i Bachtins tænkning af det æstetiske, selv om denne forandring betyder et rent brud i forståelse af æstetikkens særegenhed, en omvurdering af alle æstetiske værdier. Således mener vi, at der både er kontinuitet, modsigelser og brud i Bachtins forfatterskab, og som det forhåbentligt er fremgået, har fremkomsten af de tidlige tekster givet mulighed for at forstå det dynamiske i både kontinuiteten, modsigelserne og bruddene. Bachtin var gennem hele sit liv en tænker, som aldrig lod sig begrænse eller hæmme af, at han ikke fik alt til at gå op i en højere syntetisk enhed, men tværtimod lod sin tænkning drive frem og tilbage, gennem gentagelser og nyopdagelser, i en bevægelse som aldrig fandt sin afslutning - og som aldrig var uden moralsk, eksistentiel eller værdimæssig betydningsladning. På denne måde synes Bachtins forfatterskab at være en perfekt illustration af dets egne tanker.

Tilbage står måske blot at fremhæve, at Bachtins tænkning, hans moralske, eksistentielle og værdimæssige tilgang til litteraturen, kulturen og ikke mindst 
menneskets væren i verden, altid bæres frem af en indtagende og aldrig svigtende optimisme, endnu en af de understrømme, der løber gennem hele forfatterskabet. Men man må undre sig over denne optimisme: Bachtin led gennem hovedparten af sit liv af en smertefuld knoglesygdom; han levede under stalinismens totalitære regime, som adskilte ham fra hans bror, sendte ham $i$ indre exil, udrensede en række af hans venner og lod hans karriere blive alt andet end guldrandet. Måske havde han, som de jævnaldrende i Vesten, det synes mest oplagt at sammenligne ham med, også sin forestilling om et hinsides: »For Lukàcs var den anden side det klasseløse samfund, for Benjamin en messiansk nu-tid, og for Bloch det, der endnu ikke var færdigt, det der bevægede sig i det mørke, blå, i hjertet af objekterne. $«{ }^{17}$ Hvad det var, der fik Bachtin til trods alt at skabe en art håbets filosofi på sprogvidenskabelige og moralske principper, hvilket 'hinsides' Bachtin drømte om - det står stadig tilbage at vise.

\section{Noter}

1. M.M. Bachtin: Art and Answerability, Austin 1990, pp. 188-189.

2. Jvf. Paul de Man: »Dialogue and dialogism«, p. 110-111; in Morson/Emerson (ed.): Rethinking Bakhtin. Extentions and Challenges, Illinois 1989.

3. Denne tanke er vi ikke alene om; Todorov har på glimrende vis argumenteret for samme idé i sin bog om Bachtin: Mikhail Bakhtin. The Dialogical Principle, Manchester 1984. Men i modsætning til Todorov, som udelukkende ser denne sammenhæng hos Bachtin og ellers kun får øje på uophævelige modsigelser, har vi, som det vil fremgå, en anden forestilling om Bachtins forfatterskab.

4. Samme afgrænsning findes bl.a. hos Clark/Holquist Mikhail Bakhtin, London 1984, p.3. Der er dog en central problematik, vi må nævne i denne forbindelse, og som Brian Poole har belyst, bl.a. i et for os inspirerende essay »From Phenomenology to Dialogue - Max Schelers Phenomenological tradition and Mikhail Bakhtin's Development form Toward a Philosophy of the Act to his study of Dostojevsky « (trykkes i 2. udgave af Hirschkop/Shepherd (ed.): Bakhtin and Cultural Theory som skulle udkomme efteråret 1998). Poole argumenterer for, at Bachtins to tekster »Mod en handlingens filosofi « og »Forfatter og helt i æstetisk aktivitet « næppe er skrevet før 1927, og Poole antyder samtidig, at Bachtin derfor næppe er forfatteren til »Problemet om indhold...«, som nærmere skulle stamme fra Medvedev. Den sidste påstand ser vi bort fra i denne artikel. Heller ikke Pooles argumenter kan vi kommentere nærmere her, men vores opfattelse af den tidlige del af Bachtins forfatterskab vil ikke ændres stort, hvis Poole har ret: De tidlige tekster er stadigvæk en mere eller mindre selvstændig del, som peger på både en kontinuitet og en diskontinuitet i Bachtins hele forfatterskab.

5. Vi refererer til de amerikanske oversættelser af Bachtins tekster, og det drejer sig her om Art and Answerability. Early Philosophical Essays, Austin 1990 og Toward a Philosophy of the Act, Austin 1993. I det følgende vil referencerne til de tre essays fra Art and Answerability. Early Philosophical Essays være forkortet således: 
»Art and Answerability«: (»AA«), »Author and Hero in Aesthetic Activity«: (»AH«) og »The Problem of Content, Material, and Form in Verbal Art«: (»PC«), mens det lille bind Toward a Philosophy of the Act forkortes Act. Med undtagelse af citatet fra »AA«, oversat af Nina Møller Andersen i dette nummer af $K \& K$, har vi selv oversat titler og citater i artiklen; kursiveringer i citaterne er Bachtins egne.

6. Se Clark/Holquist: Mikhail Bakhtin, London 1984, p.54, samt Holquists forord i Art and Answerability. Early Philosophical Essays «, Austin 1990, p. xix. Det er dog begge steder uklart, om udtrykket er en oversættelse af en titel, som Bachtin selv har benyttet.

7. Med denne læsning af »Kunst og ansvarlighed « kan den betragtes som forløberen for »Mod en handlingens filosofi«. Men som Emerson og Morson har påpeget kan den lille artikel også læses som et opgør med formalismen og helt specifikt som et 'svar' på Skhlovskijs klassiske programerklæring »Art as Device« fra 1917 (jvf. Morson/Emerson: Mikhail Bakhtin. Creation of a Prosaics, Stanford 1991, pp. 7174). At det i øvrigt er nærliggende at tænke på avantgardens drøm om foreningen af kunst og liv skyldes, at Bachtin mellem 1918 og 1924 boede i de to byer, Nevel og Vitebsk, hvor der i den spæde og frie postrevoltutionære periode var stærke avantgardiske strømninger, som i en vis udstrækning - omend tidsmæssig kortvarigt - lod kunst og liv forenes (jvf. Clark/Holquist: Mikhail Bakhtin, London 1984, kap. 2); men det vil i løbet af denne artikel blive klart, at Bachtin tænker i en anden retning.

8. Vi har fors $\emptyset \mathrm{gt}$ at holde lidt mere orden på begreberne end Bachtin selv gør, og væsentligst skal det fremhæves, at da Bachtin ikke selv opererer med en strikt terminologisk skelnen mellem etik og moralfilosofi, har vi indført den her for at klargøre hans position. Med etik mener vi således en normativ etik, hvor der reflekteres over almengyldige normer for en etisk handlen; mens moralfilosofi står for refleksionen over, hvilke handlinger, der kan karakteriseres som moralske og på hvilket grundlag dette sker (erkendelsesteoretisk, sprogfilosofisk, ontologisk mv.). Man kan således sige, at Bachtins moralfilosofi har klare metaetiske undertoner, men som det vil fremgå er Bachtins projekt et helt andet, nemlig etableringen af en normativ filosofisk antropologi. I $\emptyset$ vrigt kan det nævnes, at Bachtins inspiration fra Scheler og Nicolai Hartmann også viser sig i Bachtins moralfilosofiske projekt. Jvf. for en uddybelse nævnte artikel af Brian Poole i note 4.

9. Det kan være relevant at påpege, at Bachtins diskussion af det splittede og det ikkesammenfaldende subjekt skal forstås hver for sig, så at sige. Det splittede subjekt er resultatet af moderniseringsprocessernes afkast af fremmedgørelsen, instrumentel fornuft osv., som Bachtin diskuterer i en modernitetskritisk tankegang parallelt med størstedelen af modernitetskritikerne fra slutningen af det 19. århundrede, begyndelsen af det 20. århundrede. Idealet for Bachtin er imidlertid, i hvert fald når det gælder hans filosofiske antropologi, ikke det 'hele', autonome subjekt, men netop det åbne og udviklende subjekt. Disse forhold bliver diskuteret i Bachtins bog om Dostojevskij, men vi må afholde os fra en nærmere diskussion af dem her.

10. Der er både $\mathrm{i} »$ Mod en handlingens filosofi $\ll$ og $\mathrm{i} »$ Forfatter og helt $\mathrm{i}$ æstetisk aktivitet « en analyse af selvsamme Pusjkin-digt, og de adskiller sig på visse måder fra hinanden. Det vil dog føre for langt at diskutere det nærmere her, hvor målet er en overordnet introduktion.

11. Det bør for en god ordens skyld bemærkes, at vi ikke gennemgår alle de æstetiske kategorier, Bachtin arbejder med, f.eks. skal vi ikke diskutere ideen om den æstetiske kærlighed, isolering osv. Vi holder os til de store hovedlinjer - men vi må 
notere, at ved kontemplation forstår Bachtin både forfatterens og læserens holdning til kunstværket, og at når Bachtin taler om forfatteren, så mener han ikke den biografiske forfatter, men den implicitte, værkimmanente forfatter(-position), der er tilstede som en del af det strukturende princip i ethvert kunstværk. Det er i $\varnothing$ vrigt ikke mindst disse kategorier, Bachtin har hentet hos Scheler, hvilket Brian Poole glimrende viser, ligesom han har påpeget, at Bachtins originalitet består i at overføre disse kategorier til æstetikkens område. (Se også note 4.)

12. Jvf. M.M. Bachtin: Problems of Dostoevsky's Poetics, Minneapolis 1984 pp.54ff.

13. En række af de pointer, Bachtin fremfører i dette essay mod formalisterne, findes i mere udfoldet udgave i Medvedevs bog The Formal Method in Literary Scholarship. A Critical Introduction to Sociological Poetics, London 1991, som er ganske oplysende at læse i forlængelse af dette essay.

14. Jvf. Clark/Holquist, Mikhail Bakhtin, London 1984, p.65.

15. At Bachtin beskæftigede sig intensivt med religion og religiøse emner kan der næppe herske tvivl om, men det er diskuterbart i hvilken udtrækning dette gør sig gældende i hans egne værker. Holquist/Clark gør sig til talsmænd for, at Bachtin grundlæggende er en religiøs tænker, men dette er efter vores overbevisning en overdrivelse.

16. Dette værdielement støder man konstant på under læsningen af Bachtins tekster, og nogle år senere går det under navnet ideologi - parallelt med Medvedevs og Volosjinovs tekster. Hermed markeres den sociologiserende og politiserende tendens, som er så fraværende hos den helt tidlige Bachtin, men retrospektivt er det ikke vanskeligt at opfange kontinuiteten: Den værdiorienterede holdning er overalt central for Bachtin.

17. Se Henning Goldbæks »Ernst Bloch: En utålmodig kulturkritiker« in Ernst Bloch: Spor, København u.å., p. 211. 